\title{
PERANCANGAN GEDUNG FAKULTAS TEKNIK UNSRAT DENGAN PERSPEKTIF ANIMASI 3D
}

\author{
Marfil Vialli Rompas, Alicia Sinsuw, Jimmy Robot, Xaverius Najoan \\ Program Studi Teknik Informatika, Fakultas Teknik, Universitas Sam Ratulangi \\ Jl. Kampus UNSRAT Bahu, Manado, 95115 \\ Telp : (0431) 852959, Fax : (0431) 823705 \\ E-mail : marfilrompas@gmail.com
}

\begin{abstract}
Abstrak
Model Gedung Fakultas Teknik yang biasanya hanya berbentuk gambar dibuat model berupa 3D dalam bentuk Animasi. Produksi Film Animasi Gedung Fakultas Teknik Universitas Sam Ratulangi dengan perspektif animasi 3D ini menggunakan teknik tracking camera. Tracking camera merupakan cara untuk melihat dari model 3D yang dibuat dengan pandangan camera yang berjalan sendiri. Pemodelan gedung berdasarkan gambar gedung hasil observasi yang dibuat menjadi model 3D. Hasil akhir dari pembuatan film animasi 3D dari gedung Fakultas Teknik Unsrat ini diharapkan dapat menjadikan gedung Fakultas Teknik Unsrat dalam bentuk animasi 3D yang dapat membantu user atau mahasiswa untuk lebih mengetahui daerah gedung Fakultas Teknik Unsrat ini. Selain itu melalui pembuatan film animasi 3D dari model gedung ini juga diharapkan dapat digunakan sebagai modul presentasi untuk memperkenalkan gedung Fakultas Teknik Unsrat kepada pihak luar.
\end{abstract}

Kata kunci: Film Animasi, Model 3D, Tracking Camera

\section{PENDAHULUAN}

Dewasa ini marak dengan perkembangan konten-konten multimedia yang berhubungan dengan desain atau model dari suatu bangunan dalam bentuk model 3D, misalnya melalui media televisi yang menayangkan tentang konsep suatu perumahan atau gedung dalam bentuk 3D yang digunakan untuk keperluan promosi dari produk tersebut.

Berbicara mengenai produk yang ditayangkan melalui media televisi, produk tersebut bisa berupa model 3D, dari sebuah perumahan, hotel, rumah dan lain - lain. Tetapi produk tersebut hanyalah berupa sebuah gambar dari porduk yang tampak dari depan, samping, atau perspektif. Tidak merupakan pembuatan objek 3D secara secara kompleks.

Pada tugas akhir ini akan dibuat sebuah animasi 3D dari model gedung Fakultas Teknik Universitas Sam Ratulangi. Animasi ini menggunakan teknik tracking camera. Tracking camera merupakan cara untuk melihat dari model 3D yang dibuat dengan pandangan camera yang berjalan sendiri. Model 3D diambil dari sample gedung Fakultas Teknik Unsrat yang akan dibuat model 3D. Kemudian diberi texture serta mengatur lighting dan digabungkan dengan teknik tracking camera setelah itu dirender untuk dijadikan sebuah animasi 3D dari gedung Fakultas Teknik Unsrat.
Hasil akhir dari pembuatan model 3D dari gedung Fakultas Teknik Unsrat ini diharapkan dapat menjadikan gedung Fakultas Teknik Unsrat dalam bentuk animasi 3D yang dapat membantu user atau mahasiswa untuk lebih mengetahui daerah gedung Fakultas Teknik Unsrat ini. Selain itu melalui pembuatan animasi 3D dari model gedung ini juga diharapkan dapat digunakan sebagai modul presentasi untuk memperkenalkan gedung Fakultas Teknik Unsrat kepada pihak luar.

\section{LANDASAN TEORI}

\section{A. Fakultas Teknik}

Pada tahun lima puluhan, satu-satunya

Pendidikan Tinggi di Sulawesi Utara-Tengah adalah Perguruan Tinggi Pendidikan Guru (PTPG) yang ada di Tondano. Akibat pergolakan di sekitar tahun enam puluhan, lembaga pendidikan tinggi ini khususnya dan lembaga pendidikan pada umumnya, tidak dapat menjalankan misinya sebagaimana mestinya, dan setelah kondisi kembali normal dirasakan kemunduran dalam dunia pendidikan. Atas inisiatif dari beberapa tokoh pendidikan, maka berdirilah beberapa Fakultas yang akhirnya berkembang dalam satu lembaga dengan nama Universitas Sulawesi Utara-Tengah (Unsulutteng).

Perkembangan fakultas-fakultas yang ada pada waktu itu memotivasi pimpinan universitas untuk membuka Fakultas Teknik. Melalui Rapat 
Senat Guru Besar pada tanggal 9 September 1962 dibentuklah Panitia Persiapan Pembentukan Fakultas Teknik yang juga melibatkan beberapa pimpinan instansi diluar universitas yaitu Kepala Dinas Pekerjaan Umum Sulutteng, Kepala Perusahaan Listrik Negara Exploitasi V Sulutteng, Kepala Perwakilan Direktorat Pertambangan Manado, PT. Shell Indonesia Perwakilan Manado, dan STM Negeri Manado.

Dengan Surat Keputusan Menteri PTIP No. 132 tanggal 22 Oktober 1964, terhitung mulai tanggal 1 September 1964 dinyatakan berdirinya Fakultas Teknik dalam lingkungan Unsulutteng, yang kemudian dikenal dengan nama Universitas Sam Ratulangi.

\section{B. Multimedia}

Dalam industri elektronika, multimedia adalah kombinasi dari komputer dan video atau multimedia secara umum merupakan kombinasi dari tiga elemen yaitu suara, gambar dan teks atau multimedia adalah kombinasi dari paling sedikit dua media input atau output dari data media ini dapat audio (suara, musik) animasi, video, teks, grafik dan gambar atau multimedia merupakan alat yang dapat menciptakan presentasi yang dinamis dan interaktif yang mengkombinasikan teks, grafik, animasi, audio dan gambar video ( Suyanto M, 2005).

\section{Animasi}

Definisi animasi sendiri berasal dari kata 'to animate' yang berarti menggerakkan, menghidupkan. Misalkan sebuah benda yang mati, lalu digerakkan melalui perubahan sedikit demi sedikit dan teratur sehingga memberikan kesan hidup. Animasi adalah proses penciptaan efek gerak atau efek perubahan bentuk yang terjadi selama beberapa waktu. Animasi juga merupakan suatu teknik menampilkan gambar berurut sedemikian rupa sehingga penonton merasakan adanya ilustrasi gerakan (motion) pada gambar yang ditampilkan. Definisi tersebut mengartikan bahwa benda-benda mati dapat 'dihidupkan'. Pengertian tersebut hanyalah merupakan istilah yang memiripkan, dalam arti tidak harus diterjemahkan secara denotatif, melainkan simbol yang menyatakan unsur kedekatan. (Djalle, Zaharuddin 2007).

\section{Produksi Film Animasi 3D}

Secara umum siklus produksi dalam pembuatan film meliputi beberapa thapan dan berdasarkan depth interview dengan pihak studio animasi kojoanima serta literatur produksi film animasi, yaitu: tahap development, proses pengumpulan ide - ide dan pengembangan ide; pra produksi, didalamnya proses pengembangan skenario, storyboard, pembagian tugas, penjadwalan, dan sebagainya; tahap produksi, berupa tahapan proses animasi; tahap pasca produksi, merupakan tahapan editing, penggabungan dari masing - masing komponen dalam film; distribusi termasuk ke dalamnya proses penjualan (Diana Sari, 2012).

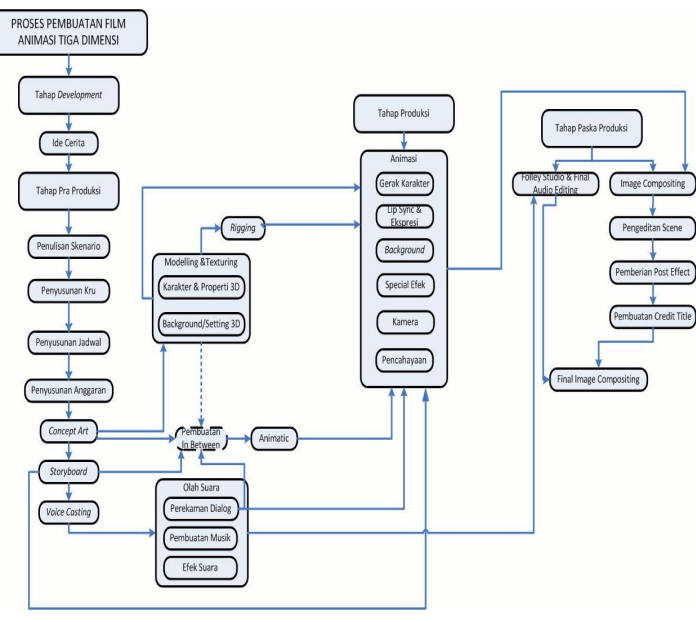

Gambar 1. Alur Proses Bisnis Produksi Film Animasi 3D

\section{METODOLOGI PENELITIAN}

A. Kerangka Penelitian Film Animasi 3D

Pembuatan produksi film animasi ini mengikuti proses produksi film animasi 3D dari sumber kompilasi Maestri, 2006; Chapman; Animation Workflow; Pixar; dan Kojoanima (Diana Sari, 2012). Pada produksi film animasi 3D untuk pengembangan Groupware.

Pada pembuatan tugas akhir ini yang dilakukan tidak dalam bentuk group yang hanya menghasilkan film pendek sehingga dalam perancangan ini menjadi 4 tahapan pembuatan film animasi 3D yaitu Development, Pra Produksi, Produksi, dan Pasca produksi.

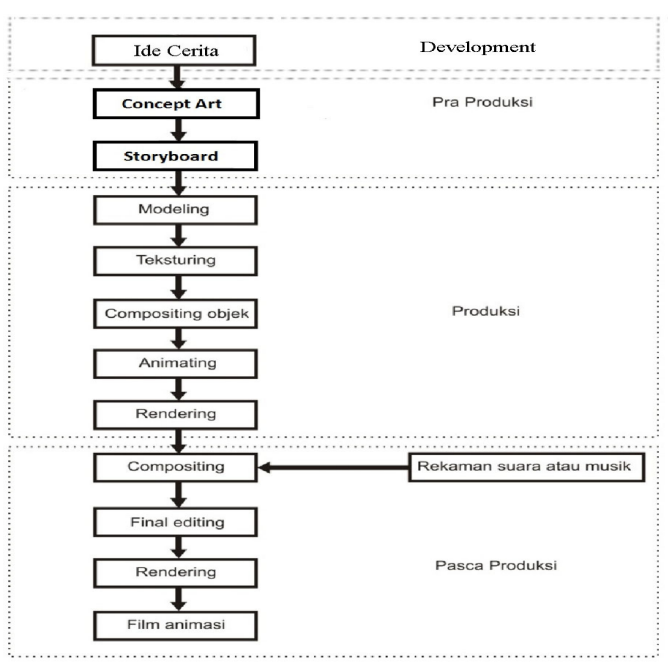

Gambar 2. Kerangka Penelitian Film Animasi 3D

B. Development 
Pada tahap ini kebutuhan yang diperlukan untuk proses development film pendek animasi 3D seperti:

\section{1). Ide Cerita}

Ide pembuatan animasi ini didapat dari hasil pengamatan dan hasil konsultasi dengan beberapa dosen. Pemodelan animasi 3D gedung kampus Fakultas Teknik Unsrat. Di film ini di tampilkan gedung - gedung dari Fakultas Teknik mulai dari Elektro, Sipil, Arsitektur dan Mesin.

\section{Pra Produksi}

Pada tahap ini semua keperluan dalam proses produksi film animasi mulai disiapkan. Beberapa hal yang perlu diperhatikan dalam tahap ini adalah :

\section{1). Concept Art}

Tahap ini merupakan persiapan awal sebelum memasuki tahap produksi film animasi 3D. Pada tahap ini sudah mulai membuat gambar gambar sketsa, mulai dari objek gedung Fakultas Teknik Unsrat, property serta sketsa lingkungan eksterior dan interior.

\section{2). Storyboard}

Pada saat skenario dan concept art sudah rampung selanjutnya ide tersebut di gambarkan dalam bentuk storyboard agar nantinya proses pengerjaan film animasi 3D ini akan menjadi lebih mudah dan terarah.

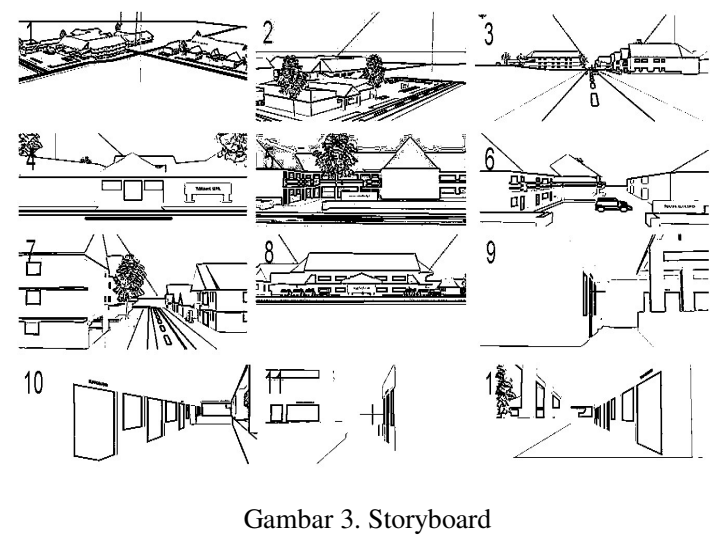

\section{PEMBAHASAN}

Hasil dan pembahasan proses pembuatan model animasi 3D dari gedung Fakultas Teknik Unsrat ini menjelaskan tentang proses produksi yaitu mulai dari memodelkan gedung Fakultas Teknik dalam bentuk 3D sampai pada tahap pasca produksi dari pembuatan animasi 3D ini.

\section{A. Produksi}

Proses produksi dari film animasi terdiri dari beberapa tahap yaitu modeling, texturing, animating dan rendering.

1). Modeling dan Texturing
Modeling adalah proses pembuatan sebuah objek. Dimana proses pembuatan objek ini menggunakan tools pada blender. Seperti tools mesh yang terdiri dari plane, cube, circle, UV sphere, icosphere, cylinder, cone, grid, monkey dan lain- lain yang bisa dipakai untuk memodelkan sebuah objek sesuai yang kita inginkan.

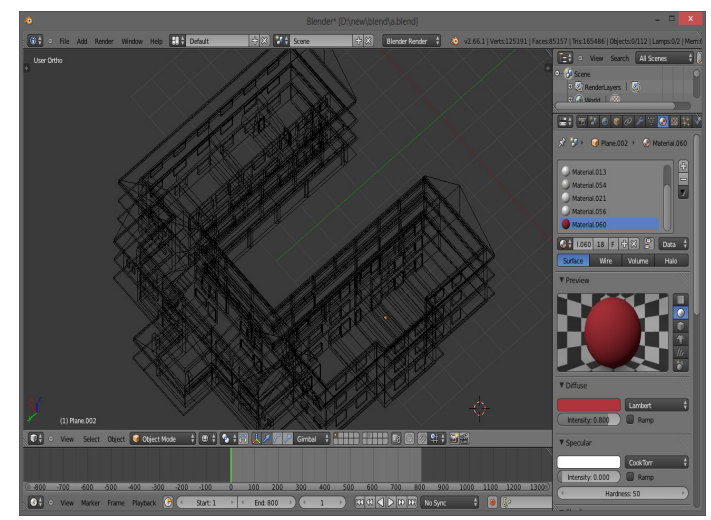

Gambar 4 . Modeling Gedung Fakultas Teknik

Texturing adalah proses pemberian texture atau material pada sebuah objek sehingga menjadi sesuai dengan yang kita inginkan. Proses texturing pada program blender dapat dibuat dengan menggunakan tools material dan tools texture.

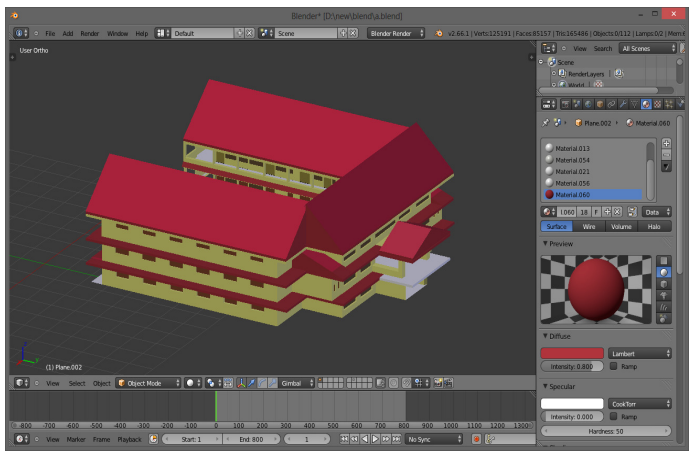

Gambar 5. Texturing Gedung Fakultas Teknik

\section{2). Tracking Camera}

Tracking Camera merupakan cara untuk melihat model gedung 3D yang dibuat dengan animasinya berupa camera yang berjalan sendiri mengikuti lintasan atau path yang telah kita buat.

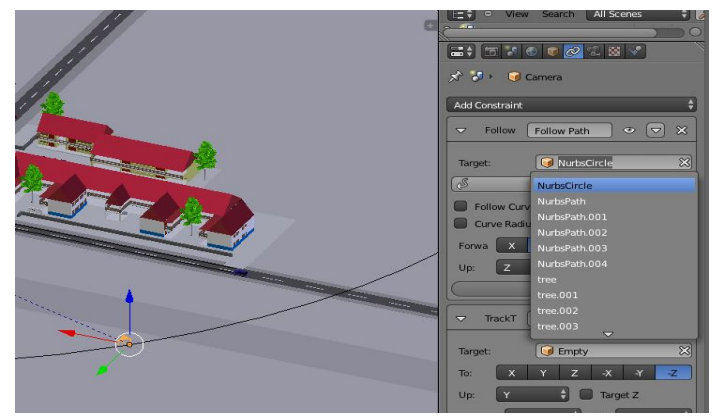

Gambar 6. Menentukan Target Camera

3). Pengaturan Camera 
Pengaturan kamera dilakukan untuk mendapatkan suatu sudut pandang adegan yang sesuai dengan yang kita inginkan. Langkah awal untuk melakukan pengaturan kamera adalah dengan menambahkan kamera pada tiap scene yang telah dibuat dengan menekan tombol shift + a dan pada menu add pilih camera.

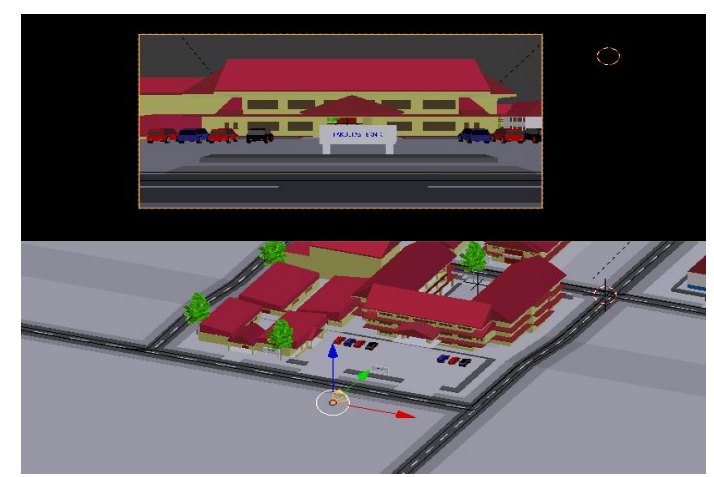

Gambar 7. Pengaturan Sudut Pandang Kamera

B. Pasca Produksi

Pada bagian ini merupakan proses akhir dari pembuatan model animasi 3D dari Gedung Fakultas Teknik Unsrat. Dimana pada proses pasca produksi inilah semua file hasil rendering dari bagian produksi digabungkan dan di tambahkan file audio. Bagian ini terbagi menjadi bagain compositing dan editing serta rendering dan penentuan video compsition code.

\section{1). Compositing dan Editing Video}

Proses compositing dan video editing ini merupakan tahap yang penting. Karena pada tahap ini dilakukan penggabungan dari beberapa elemen seperti video hasil dari rendering animasi beserta seluruh bagiannya, gambar atau image juga audio. Sehingga dapat menghasilkan suatu output film yang menarik.

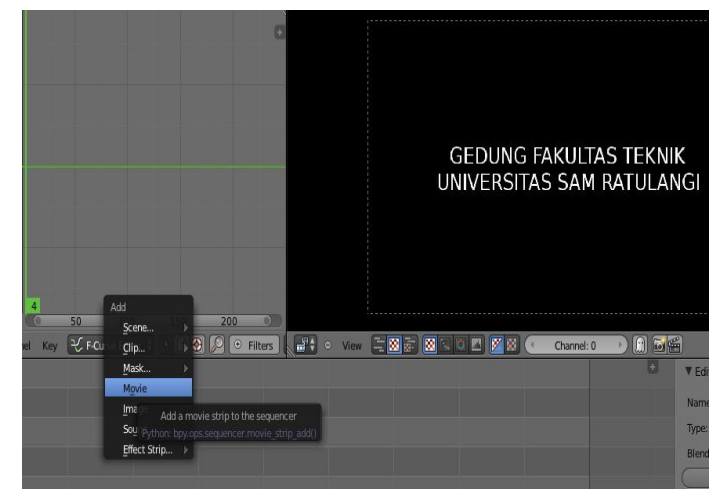

Gambar 8. Menambahkan File pada Video Editing Blender
Code

Tahap ini merupakan tahap terakhir dari semua proses pembuatan model animasi 3D dari Gedung Kampus Fakultas Teknik Unsrat. Proses untuk membuat semua file hasil dari compositing dan editing video di render kembali menjadi satu film utuh.

Untuk melakukan rendering terlebih dahulu di tentukan format dari file hasil output nanti sesuai dengan yang di inginkan. Dalam pembuatan animasi ini menggunakan file format xvid dengan pengaturan encoding format AVI dan Codec MPEG-4(divx) dan audio codec MP3.

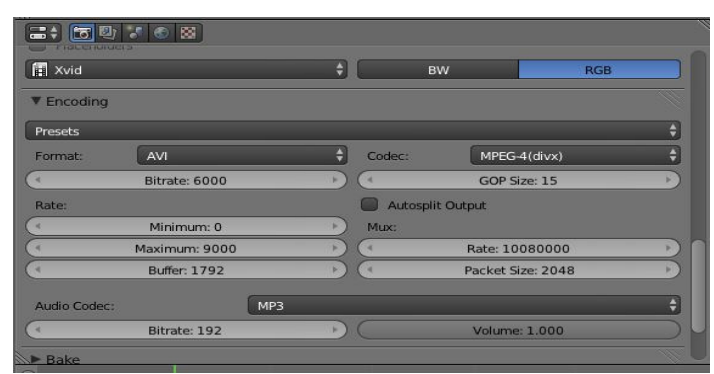

Gambar 8. File Format

Setelah semua proses pengaturan telah selesai dilakukan maka langkah selanjutnya adalah merender semua file itu dengan menekan tombol Ctrl + F12 menjadi file animasi 3D dari Gedung Fakultas Teknik Unsrat.

\section{KESIMPULAN DAN SARAN}

A. Kesimpulan

Kesimpulan yang dapat diambil setelah menyelesaikan pembuatan film animasi 3D dari Gedung Fakultas Teknik Unsrat dengan Perspektif animasi 3D ini adalah :

1. Dengan menggunakan texture pada model 3D Gedung Fakultas Teknik Unsrat dapat membuat tampilan film animasi semakin menarik.

2. Dengan men-setting lighting pada model 3D gedung Fakultas Teknik Unsrat dapat membuat pantulan bayangan dari objek dalam film animasi.

3. Teknik tracking camera digunakan untuk menggabungkan model 3D gedung Fakultas Teknik Unsrat sehingga menampilkan animasi berupa camera yang berjalan mengikuti lintasan yang telah dibuat.

4. Untuk hasil rendering pembuatan film animasi ini menggunakan file format xvid dengan pengaturan encoding format AVI dan Codec MPEG- 4(divx) dan audio codec MP3. 
Untuk saran dari pembuatan Gedung Fakultas Teknik Unsrat dengan Perspektif animasi 3D ini adalah :

1. Dalam proses pembuatan animasi sebaiknya dilakukan secara tim karena dengan bekerja tim akan dapat menghasilkan animasi yang lebih maksimal serta dapat menghemat waktu pengerjaan animasi 3D.

2. Untuk proses pembuatan animasi khususnya pada proses rendering dari animasi 3D sebaiknya di gunakan komputer dengan spesifikasi yang memadai karena lama dari waktu rendering itu tergantung dari baik tidaknya komputer yang digunakan.

3. Dan untuk pengembangan pembuatan animasi selanjutnya diharapkan dapat di tambahkan penggunaan mouse engine untuk animasi yang lebih interaktif.

\section{DAFTAR RUJUKAN}

[1] Darma, Jarot S. dan Shenia Ananda. 2009. Buku pintar menguasai multimedia .Jakarta. Mendiakita

[2] Djalle, Zaharuddin. Purwantoro, Edi. Dasmana, Demi. 2007. Animation Using 3D Studio Max. Bandung. Informatika.

[3] Kusrianto, A. 2009. Berkarier di dunia grafis. Jakarta. PT Elex Media Komputindo.

[4] Rinaldi, J. 2012. Perancangan Tutorial Penerimaan Mahasiswa Baru Universitas Sam Ratulangi Berbasis Animasi 3D. Skripsi S1 Teknik Elektro Universitas Sam Ratulangi. Manado.

[5] Rosyid, A. 2012. Pembuatan Model 3D dari Gedung D4 PENS-ITS. Teknologi Multimedia Broadcasting, Institut Teknologi Sepuluh Nopember. Surabaya.

[6] Sari, D. 2012. Perencanaan Kebutuhan Pengguna Pada Produksi Film Animasi Tiga Dimensi Untuk Pengembangan Groupware. Pusat Penelitian dan Pengembangan Penyelenggaraan Pos dan Informatika, Kementerian Komunikasi dan Informatika. Jakarta.

[7] Suyanto, M. dan Yuniawan, Aryanto. 2006. Merancang Film Kartun Kelas Dunia. Yogyakarta. Andi Offset.

[8] Suyanto, M. 2005. Multimedia Alat Untuk Meningkatkan Keunggulan Bersaing. Yogyakarta. Andi Offset.

[9] Suyanto, M. 2006. Analisis \& Desain Aplikasi Multimedia untuk Pemasaran. Yogyakarta. Andi Offset.

[10] www.blender.org, 7 Maret 2013

[11] www.fatek.unsrat.ac.id, 10 Juli 2013

[12] www.makehuman.org, 14 Juli 2013 